\title{
Potential area and limitations for the expansion of rainfed wheat in the Cerrado biome of Central Brazil
}

\author{
Aldemir Pasinato(1), Gilberto Rocca da Cunha( ${ }^{(1)}$, Denise Cybis Fontana ${ }^{(2)}$, \\ Jose Eduardo Boffino de Almeida Monteiro( ${ }^{(3)}$, Alan Massaru Nakai ${ }^{(3)}$ and Aryeverton Fortes de Oliveira ${ }^{(3)}$
}

\begin{abstract}
(1)EmbrapaTrigo, RodoviaBR-285,Km294,CaixaPostal3081,CEP99050-970PassoFundo, RS, Brazil.E-mail:aldemir.pasinato@embrapa.br, gilberto.cunha@embrapa.br (2)Universidade Federal do Rio Grande do Sul, Departamento de Plantas Forrageiras e Agrometeorologia, Avenida Bento Gonçalves, no 7.712, Agronomia, CEP 91540-000 Porto Alegre, RS, Brazil. E-mail: dfontana@ufrgs.br ${ }^{(3)}$ Embrapa Informática Agropecuária, Avenida André Tosello, no 209, Campus da Unicamp, Barão Geraldo, Caixa Postal 6041, CEP 13083-886 Campinas, SP, Brazil. E-mail: eduardo.monteiro@embrapa.br, alan.nakai@embrapa.br, ary.fortes@embrapa.br
\end{abstract}

\begin{abstract}
The objective of this work was to locate and quantify, through geotechnologies, areas that are currently used for annual agriculture in the Cerrado biome of Central Brazil, located within the boundaries defined by the homogeneous region of adaptation of wheat cultivars 4 and that present favorable conditions for rainfed wheat (Triticum aestivum) cultivation. The following information layers were crossed: use and coverage of the Cerrado biome, digital elevation model, and water requirement satisfaction index for wheat in the Cerrado biome. In addition, different levels of water stress (low, moderate, and high), risk levels (20, 30 , and $40 \%$ ), available soil water capacities (ASWCs) $(35,55$, and $75 \mathrm{~mm})$, cultivar cycles $(105,115$, and 125 days), and sowing dates (in February and March) were also considered. A greater favorable area was observed for sowing in early February, and group I of cultivars (105 days) presented the greatest favorable area. Above $800 \mathrm{~m}$ altitude, 2.7 million hectares were classified as favorable for the best combination of factors, i.e., sowing on February 5, ASWC of 75 mm, 105-day cycle, 20\% risk level, and low and moderate impacts.
\end{abstract}

Index terms: Triticum aestivum, agricultural zoning, climatic risk, territorial management, tropical wheat.

\section{Área potencial e limitações para a expansão de trigo de sequeiro no bioma Cerrado do Brasil Central}

Resumo - O objetivo deste trabalho foi localizar e quantificar, por meio de geotecnologias, áreas atualmente utilizadas em agricultura anual no bioma Cerrado do Brasil Central, localizadas no interior dos contornos definidos pela região homogênea de adaptação de cultivares de trigo 4 e que apresentem aptidão favorável para o cultivo de trigo (Triticum aestivum) no regime sequeiro. Foram realizados cruzamentos dos seguintes planos de informação: uso e cobertura das terras do bioma Cerrado, modelo digital de elevação e índice de satisfação de necessidades de água para trigo no bioma Cerrado. Também foram considerados níveis de impacto de estresse hídrico (baixo, moderado e elevado), níveis de risco (20, 30 e 40\%), capacidades de armazenamento de água disponível (CAD) no solo (35, 55 e $75 \mathrm{~mm}$ ), ciclos de cultivares (105, 115 e 125 dias) e semeaduras (em fevereiro e março). Há maior área favorável para semeaduras no começo de fevereiro, e o grupo I de cultivares (105 dias) apresentou a maior área favorável. Acima de $800 \mathrm{~m}$ de altitude, 2,7 milhões de hectares foram classificados como favoráveis para a melhor combinação de fatores, isto é, semeadura em 5 de fevereiro, CAD de $75 \mathrm{~mm}$, ciclo de 105 dias, nível de risco de $20 \%$, e impactos baixo e moderado.

Termos para indexação: Triticum aestivum, zoneamento agrícola, risco climático, gestão territorial, trigo tropical.

\section{Introduction}

In Brazil, expanding wheat (Triticum aestivum L.) cultivation to areas beyond the temperate zone in the Southern region, which currently comprises $90 \%$ of the cultivated and wheat producing area of the country (Conab, 2017), requires finding production alternatives to both supply the domestic market and generate surpluses for export. Therefore, there is great potential to expand wheat production in the tropical zone, in the Southern and Midwestern regions, especially in the Cerrado biome, in which the area occupied by wheat crops was only approximately 120 thousand hectares in 2016 (Conab, 2017). 
Although the Cerrado biome is not traditionally used for wheat cultivation, it shows potential for the expansion of the production of this cereal (Cargnin et al., 2009; Farias et al., 2016; Pasinato, 2017) due to the following advantages: proximity to the main wheat consumers in the Southeastern region of country; vast areas cultivated with annual agriculture with the possibility of growing wheat in the off-season, particularly under rainfed cultivation; regional aptitude for the production of bread-class wheat; and the possibility of greater profits for the wheat grower since the harvesting period occurs before that of the traditional production regions in Southern Brazil.

However, there are some environmental barriers to the expansion of rainfed wheat cultivation in the Cerrado biome that are related to biotic and abiotic stresses, limiting the crop's long-term productive potential and yield stability. Among these, the disease wheat blast caused by the fungus Pyricularia oryzae stands out, because it can make production unviable in epidemic years (Maciel, 2011).

To reduce the risk of blast disease, sowing must be concentrated when the head emergence/flowering of the crop coincides with the period of less rainfall; however, this increases the risk of losses caused by water deficiency, which is considered another risk factor for this crop in the Cerrado region. It should also be highlighted that the problems related to the disease cannot be solved by either chemical or genetic control.

Due to the importance and possible expansion of the wheat crop to tropical zones in Brazil, studies based on a territorial diagnosis via geotechnologies are necessary to enable a better management of production risks and to aid in the formulation of public policies for Brazilian agriculture. In this sense, a public policy instrument for credit and rural security, i.e., agricultural climatic risk zoning (ZARC), has been made available, since 1996, by Ministério da Agricultura, Pecuária e Abastecimento (Mapa) as a technical-scientific tool to assist in the management of climatic risks in agriculture (Brasil, 2018). Based on the risk-minimization criterion, ZARC for wheat identifies and maps the areas favorable for wheat cultivation in the most diverse climatic environments of the country; in the case of rainfed wheat in the Cerrado biome, it also takes into account the impact of water deficiency on the production of this cereal (Brasil, 2016a, 2016b, 2016c, 2016d, 2016e, 2016f). As for the effect of air temperatures on wheat cultivation, the adopted criterion should identify regions with milder temperatures, because wheat, as a temperate species, can suffer stresses caused by high temperatures (Asseng et al., 2017; Mishra et al., 2017). It should be noted that the preferred areas currently used for wheat cultivation in the Cerrado biome tend to be in higheraltitude regions, where air temperatures are milder.

Moreover, the implementation costs of crops should also be considered. A viable and sustainable form of wheat expansion in the tropical region is intensifying land use in areas already consolidated with annual crops, avoiding the environmental impact of opening new areas. A challenge in this regard is obtaining and using reliable databases, which are typically made available by projects that use satellite images, such as TerraClass Cerrado (Mapeamento..., 2015). These data contribute to a better understanding of the genotype $\mathrm{x}$ environment interactions (Chenu et al., 2011; CrespoHerrera et al., 2017), which indirectly support the development of breeding strategies for wheat in the tropical region of the Cerrado biome of Central Brazil.

The objective of this work was to locate and quantify, through geotechnologies, areas that are currently used for annual agriculture in the Cerrado biome of Central Brazil, located within the boundaries defined by the homogeneous region of adaptation of wheat cultivars 4 and that present favorable conditions for rainfed wheat cultivation.

\section{Materials and Methods}

According to Cunha et al. (2011), the study area was located within the homogeneous region of adaptation of wheat cultivars 4 (HRAWC 4), which includes approximately 126 (74\%) of the 204 million hectares of the total area of the Cerrado biome. In relative terms, this biome covers almost all of Distrito Federal and of the state of Goiás; slightly more than half of the states of Mato Grosso do Sul and Minas Gerais; and approximately a fifth of the states of Bahia, Mato Grosso, and São Paulo (Figure $1 \mathrm{~A}$ and Table 1).

Three databases were used to generate the following information layers (ILs): altitude ranges, annual crops, and ZARC for rainfed wheat in Brazil. For altitude ranges, the $90-\mathrm{m}$ spatial resolution digital elevation model (DEM) of the Shuttle Radar Topography Mission (SRTM), available on the EarthExplorer data 

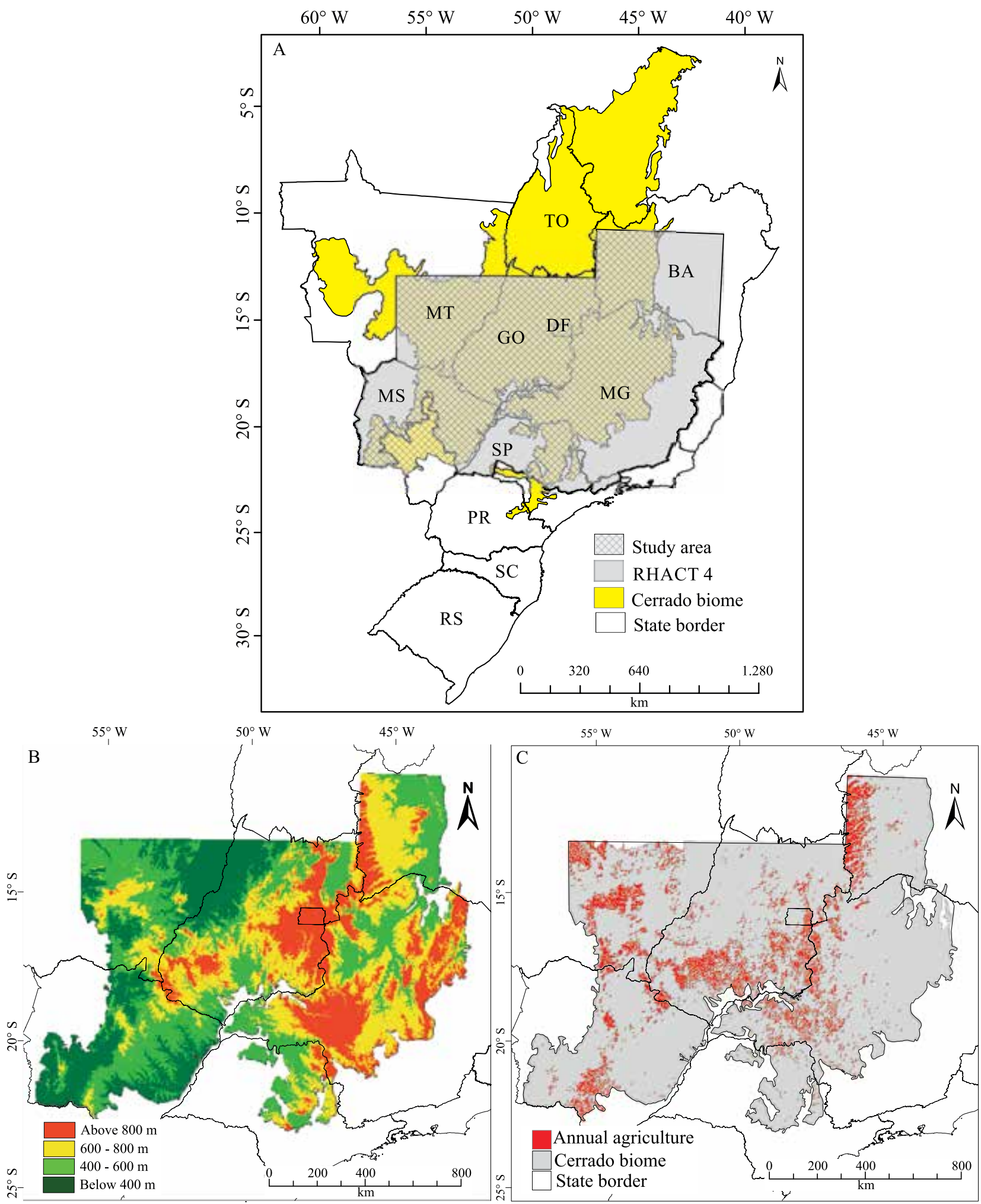

Figure 1. Maps showing: A, the study area in the Brazilian territory (TO, state of Tocantins; BA, state of Bahia; MG, state of Minas Gerais; SP, state of São Paulo; PR, state of Paraná; SC, state of Santa Catarina; RS, state of Rio Grande do Sul; MS, state of Mato Grosso do Sul; MT, state of Mato Grosso; GO, state of Goiânia; and DF, Distrito Federal); B, the distribution of the digital elevation model (DEM); and C, annual agricultural areas in the Cerrado biome. Source: adapted from Cunha et al. (2011) and Mapeamento... (2015). 
server (United States Geological Survey, 2018), was used to stratify altitude ranges lower than $400 \mathrm{~m}$, from 400 to $600 \mathrm{~m}$, from 600 to $800 \mathrm{~m}$, and higher than $800 \mathrm{~m}$ (Figure $1 \mathrm{~B}$ ). For annual crops, the land use and cover map of the Cerrado biome in 2013, created by the TerraClass Cerrado project (Mapeamento..., 2015), was used to identify "annual agricultural" areas, which were resampled to a $1-\mathrm{km}$ scale through the majority pixel value resampling technique (Figure $1 \mathrm{C})$. Finally, ZARC for rainfed wheat in Brazil was determined with the IL maps of the water requirement satisfaction index (WRSI) values generated by water balance simulations using the Sarrazon software (Baron \& Clopes, 1996), considering the available soil water capacities (ASWCs) of 35, 55, and $75 \mathrm{~mm}$. These maps aided in the identification of municipalities and favorable sowing periods for this cereal under rainfed cultivation in the 2016/2017 crop season according to cycle and soil type (Brasil, 2016a, 20126b, 2016c, 2016d, 2016e, 2016f). The frequencies of the WRSI values were analyzed from the mapping and thematic interpolation of these values, considering ten-day sowing periods centered on February and March 5, 15, and 25.

More details are found in Monteiro et al. (2017) and Pasinato (2017) regarding the parameterization of the potential evapotranspiration model for Brazil based on the Hargreaves \& Samani (1985) method; the composition of the rainfall database, including 3,500 meteorological stations of the networks of Agência Nacional de Águas (ANA) and Instituto Nacional de Meteorologia (Inmet); and the duration of the phenological phases, as well as the crop coefficient curves $(\mathrm{Kc})$, of three groups of wheat cultivars at 105 , 115 , and 125 days.

The areas favorable for rainfed wheat cultivation in 2016/2017, based on the ZARC-derived maps, were delimited and measured, considering: three cycles of standard wheat for the tropical region of Brazil at 105, 115 , and 125 days, corresponding to cultivar groups I, II, and III, respectively, according to Mapa (Brasil, 2016a, 2016b, 2016c, 2016d, 2016e, 2016f); three ASWC levels, i.e., sandy at $35 \mathrm{~mm}$, medium at $55 \mathrm{~mm}$, and clayey at $75 \mathrm{~mm}$; six stages (ten-day periods) of rainfed wheat sown on February and March 5, 15, and 25; and three levels $(20,30$, and $40 \%)$ of water-deficiency risk in the grain-filling stage (stage 3). The following three qualitative classes of water-deficiency impact on wheat, in stage 3 , were also taken into account: WRSI $\leq 0.55$, high impact; $0.55<$ WRSI $<0.70$, moderate impact; and WRSI $\geq 0.70$, low impact. A summary of this procedure is shown in Figure 2.

The ArcGIS software, version 10.0, and its tool Extract by Mask (ESRI, Redlands, CA, USA), were used to quantify the total area of the Cerrado biome in each of the federation units that comprise the HRAWC 4 - Distrito Federal and the states of Bahia, Minas Gerais, São Paulo, Mato Grosso, Mato Grosso do Sul, and Goiás -, as well as the percentage of areas classified as annual agriculture in the Cerrado biome within each unit according to the TerraClass Cerrado project (Mapeamento..., 2015). Then, within the limits

Table 1. Areas of the Cerrado biome (in 1,000 ha and as percentage) distributed per Brazilian federation unit and currently used for annual agriculture (AA) according to altitude range in the homogeneous region of adaptation of wheat (Triticum aestivum) cultivars 4 (HRAWC 4).

\begin{tabular}{|c|c|c|c|c|c|c|c|}
\hline Àrea & MG & GO and DF & MS & SP & MT & $\mathrm{BA}$ & Total \\
\hline & \multicolumn{7}{|c|}{ Area $(1,000$ ha $)$} \\
\hline Cerrado biome & 33,405 & 32,433 & 21,686 & 6,246 & 19,327 & 12,742 & 125,839 \\
\hline AA, above $800 \mathrm{~m}$ & 1,361 & 1,921 & 113 & 8 & 101 & 1,011 & 4,515 \\
\hline AA, between 600 and $800 \mathrm{~m}$ & 312 & 1,013 & 341 & 40 & 1,069 & 637 & 3,412 \\
\hline \multirow{2}{*}{ AA, between 400 and $600 \mathrm{~m}$} & 199 & 542 & 677 & 69 & 1,384 & 19 & 2,890 \\
\hline & \multicolumn{7}{|c|}{ Area $(\%)$} \\
\hline Cerrado biome ${ }^{(1)}$ & 57 & 94 & 61 & 25 & 21 & 23 & 42 \\
\hline $\mathrm{AA}^{(2)}$, above $800 \mathrm{~m}$ & 30.1 & 42.6 & 2.5 & 0.2 & 2.2 & 22.4 & 39.4 \\
\hline AA, between 600 and $800 \mathrm{~m}$ & 9.1 & 29.7 & 10.0 & 1.2 & 31.3 & 18.7 & 29.8 \\
\hline AA, between 400 and $600 \mathrm{~m}$ & 6.9 & 18.8 & 23.4 & 2.4 & 47.9 & 0.7 & 25.2 \\
\hline
\end{tabular}

(1)Proportions of the total surface area of each federation unit. (2)Proportions of the total areas in use for annual agriculture per altitude range. MG, state of Minas Gerais; GO, state of Goiás; DF, Distrito Federal; MS, state of Mato Grosso do Sul; SP, state of São Paulo; MT, state of Mato Grosso; and BA, state of Bahia. Source: Mapeamento... (2015). 
of the Cerrado biome, the ILs annual agriculture and altitude range were cross-referenced to calculate the potential wheat cultivation areas for each of the federation units. In the next stage, the IL ZARC for rainfed wheat in the 2016/2017 maps was used, and the area favorable for the cultivation of rainfed wheat was measured according to the cycles (groups), soils, sowing periods, and impact levels considered in this study. Finally, the three generated ILs - annual agriculture, ZARC rainfed wheat in 2016/2017, and altitude ranges - were cross-referenced (Figure 3). The percentage of the annual agricultural area per unit of the federation, stratified by altitude and state, was determined for each level of impact considered (low, moderate, and high), according to the minimum WRSI value and to each risk class $(20,30$, and $40 \%)$. In the absence of overlap/coincidence of areas in the IL intersections, these were considered to have other

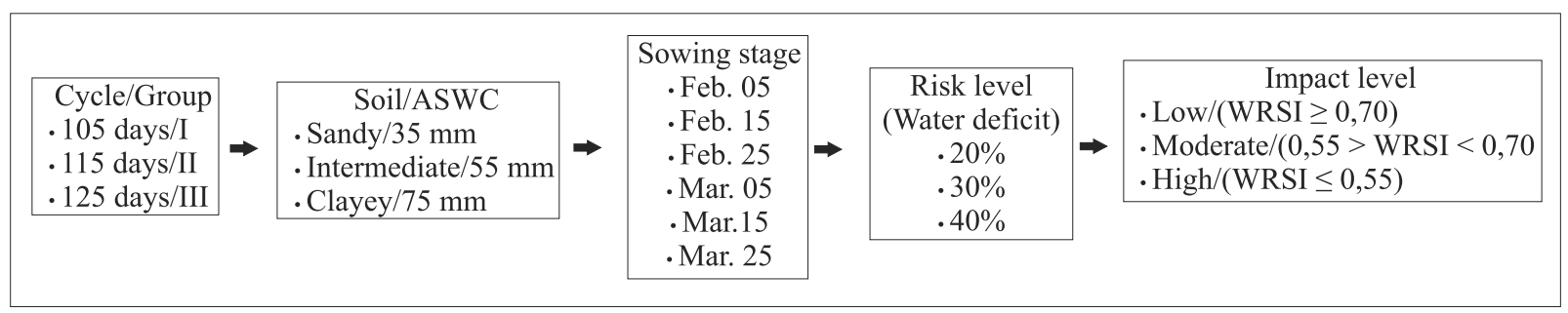

Figure 2. Parameters used for the delimitation and measurement of favorable areas for the cultivation of rainfed wheat (Triticum aestivum) based on agricultural zoning for climatic risk (ZARC) for rainfed wheat in 2016/2017. ASWC, available soil water capacity; and WRSI, water requirement satisfaction index.

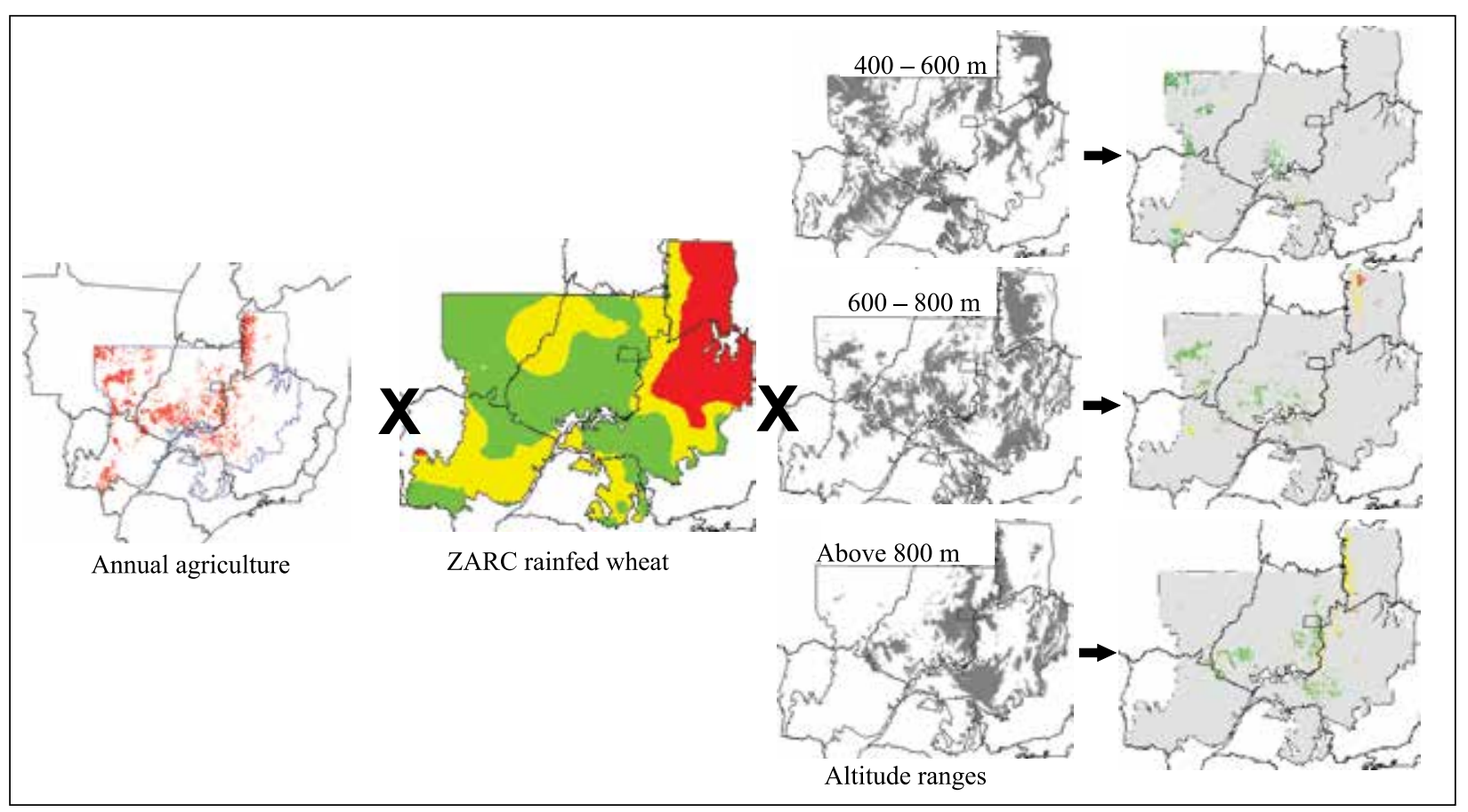

Figure 3. Cross-referencing of the information layers annual agriculture with favorable areas for rainfed wheat (Triticum aestivum), agricultural zoning for climatic risk (ZARC) in 2016/2017, and altitude. Source: adapted from Mapeamento... (2015) and Brasil (2016a, 2016b, 2016c, 2016d, 2016e, 2016f). 
uses according to the class definitions adopted by the TerraClass Cerrado project (Mapeamento..., 2015).

After the classes were generated, the areas of each one were calculated and exported to tables and grouped by cultivar cycle, soil type, and ten-day sowing period, making it possible to identify, for each level of presumed risk, the favorable area according to impact level.

\section{Results and Discussion}

The areas currently occupied with annual agriculture in the study region, according to the TerraClass Cerrado project (Mapeamento..., 2015), are distributed in all the units of the federation covered by the HRAWC 4 (Figure $1 \mathrm{C}$ ). These areas, which are already being used for soybean [Glycine max (L.) Merr.] and corn (Zea mays L.) crops, account for approximately 11.5 million hectares in the Cerrado biome and can potentially be cultivated for rainfed wheat. Furthermore, if the growing seasons of rainfed wheat and these crops do not overlap, it would not be necessary to expand the agricultural frontier beyond the current limits of annual agriculture in order to increase wheat production in Brazil, whether in the Cerrado or even in the Atlantic forest and Amazon biomes. Another alternative for intensifying land use is adopting rainfed wheat as an autumn intercrop, taking advantage of the end of the rainy season after early soybean and corn crops. This possibility supports the assertion that the sustainable intensification of land use is the most appropriate way to simultaneously meet the projected global demand for food for 2050 and preserve the environment, as emphasized by Tilman et al. (2011).

Approximately 4.5 million hectares (40\%) of the total area available for annual agricultural use, in the Cerrado biome and surrounding the HRAWC 4, is above an altitude of $800 \mathrm{~m}$, which is considered preferential (Table 1). If an intermediate altitude range of 600 to $800 \mathrm{~m}$ is considered, a further 3.4 million hectares would be incorporated. Below $600 \mathrm{~m}$, more than 3.5 million hectares would be added, of which 2.89 million hectares are in the range of 400-600 m (Table 1) and the remaining 640 thousand hectares are below $400 \mathrm{~m}$. However, since altitudes below 600 $\mathrm{m}$ may imply high-temperature restrictions on wheat cultivation in the Cerrado region, the inclusion of these areas may require varietal genetic improvement, such as the incorporation of higher heat tolerance in the wheat cultivars to be indicated for cultivation in the HRAWC 4, as previously reported by Cunha et al. (2011). Several studies, both with Brazilian (Oliveira et al., 2011) and foreign wheat (Kumar et al., 2017), show this trait can still be better explored by wheat breeding programs that use conventional or molecular markerassisted selection.

Considering the federation units that are part of the Cerrado biome and that are contained in the HRAWC 4 (Table 1), 95.1\% of the favorable areas above $800 \mathrm{~m}$ are located in Goiás, Distrito Federal, Minas Gerais, and Bahia, totaling 4.29 million hectares with potential for growing rainfed wheat. Approximately $80 \%$ of these areas in the altitude range between 600 and 800 $\mathrm{m}$, which can be considered as having intermediate conditions for rainfed wheat crop, are located in the states of Mato Grosso, Goiás, and Bahia. About half of the areas that cover the altitude range of 400-600 m, which presents less favorable conditions due to excess heat, are found in Mato Grosso (Table 1).

The general analysis of the spatial-temporal data for ZARC rainfed wheat in 2016/2017, considering all combinations of cycles, ASWCs, and sowing times, showed that a larger area is available for sowing in the first period of February in soils with $75 \mathrm{~mm}$ ASWC and low and moderate impact levels. In addition, the use of wheat cultivars of group I is the best strategy to increase the area available for wheat cultivation in the Cerrado biome.

The IL ZARC rainfed wheat in 2016/2017 was cross-referenced with the areas classified as annual agriculture at altitudes above $800 \mathrm{~m}$ and with type 3 soils with ASWC of $75 \mathrm{~mm}$. When the three groups of cultivars are considered, the delay in wheat sowing gradually decreases the low-impact area as the cultivar cycle is extended, with consequent increases in the levels of moderate and, mainly, high impacts.

Considering the number of favorable areas, group I of cultivars is the most suitable for rainfed cultivation in the Cerrado biome of Central Brazil. Assuming sowing in the first ten-day period of February and a risk level of $40 \%$, these cultivars could be planted in approximately 3.0 million hectares with a low water deficiency impact level, in 1.45 million hectares with a moderate impact, and only in 77,000 hectares with a high impact. However, assuming the lowest level of risk of $20 \%$, which was adopted as a single criterion 
by Mapa for the 2015/2016 harvest, the area decreases to 1.3 million hectares with a low water deficiency impact level, but increases to 1.4 million hectares with a moderate impact level and to 1.9 million hectares with a high impact (Table 2) (Brasil, 2015a, 2015b, 2015c, 2015d, 2015e, 2015f).

For groups II and III of cultivars, the favorable area for wheat cultivation is even more reduced and is concentrated in the first ten-day period of sowing in February. This reduction, in a temporal scale, between sowing in early February and late March is due to the impact of water deficiency during the grain-filling stage (physiological pre-maturation).

Despite improvements in wheat genetic breeding in Brazil, such as the development of cultivars that are better adapted to the dry season in the tropical region of the Cerrado, new advances are still needed. Condé et al. (2010) and Bowne et al. (2012), for example, have reported differences in the response of wheat cultivars to water deficit in Brazilian and in foreign wheats, respectively. The identification of candidate genes for drought tolerance in Brazilian wheat and the possible use of molecular markers (Poersch-Bortolon et al., 2016) indicate that wheat breeding in Brazil may be successful in the future.

The favorable areas for rainfed wheat cultivation in the study region, considering sowing in the first tenday period of February (most favorable), type 3 soil, and a $40 \%$ risk level, are located mainly in Minas Gerais, Goiás, Distrito Federal, and Bahia (Figure 4). The cross-referencing of the IL ZARC rainfed wheat in 2016/2017 showed that the areas used for annual agriculture and the altitude above $800 \mathrm{~m}$ are restrictive factors (most favorable).

Table 2. Area available in 1,000 hectares for the cultivation of rainfed wheat (Triticum aestivum) cultivars of groups I, II, and III in the homogeneous region of adaptation of wheat cultivars 4 (HRAWC 4) in the Brazilian Cerrado biome, considering risk levels of 20,30, and 40\%; low, moderate, and high water deficit impact levels for type 3 soils with an available water storage capacity of $75 \mathrm{~mm}$; and sowings centered on February and March 5, 15, and 25. The results are cross-referenced with agricultural zoning for climatic risk (ZARC) for rainfed wheat in 2016/2017, areas classified as annual agriculture, and altitudes above $800 \mathrm{~m}$.

\begin{tabular}{|c|c|c|c|c|c|c|c|c|c|}
\hline \multirow[t]{2}{*}{ Risk level (\%) } & \multicolumn{3}{|c|}{ Group I } & \multicolumn{3}{|c|}{$\begin{array}{l}\text { Group II } \\
\text { Impact level } \\
\end{array}$} & \multicolumn{3}{|c|}{ Group III } \\
\hline & Low & Moderate & High & Low & Moderate & High & Low & Moderate & High \\
\hline & \multicolumn{9}{|c|}{ February 5} \\
\hline 20 & 1,300 & 1,394 & 1,853 & 19 & 1,755 & 2,774 & - & 359 & 4,188 \\
\hline 30 & 2,211 & 1,873 & 463 & 568 & 1,886 & 2,093 & 1 & 1,374 & 3,172 \\
\hline \multirow[t]{2}{*}{40} & 3,017 & 1,453 & 77 & 1,585 & 2,225 & 738 & 245 & 1,980 & 2,322 \\
\hline & \multicolumn{9}{|c|}{ February 15} \\
\hline 20 & 4 & 1,227 & 3,317 & - & 167 & 4,380 & - & - & 4,547 \\
\hline 30 & 308 & 2,000 & 2,240 & - & 911 & 3,636 & - & 48 & 4,499 \\
\hline \multirow[t]{2}{*}{40} & 1,367 & 1,971 & 1,209 & 173 & 1,778 & 2,596 & - & 642 & 3,906 \\
\hline & \multicolumn{9}{|c|}{ February 25} \\
\hline 20 & - & 15 & 4,533 & - & - & 4,547 & - & - & 4,547 \\
\hline 30 & - & 607 & 3,941 & - & 244 & 4,303 & - & 1 & 4,546 \\
\hline \multirow[t]{2}{*}{40} & 141 & 1,629 & 2,777 & - & 451 & 4,096 & - & 13 & 4,534 \\
\hline & \multicolumn{9}{|c|}{ March 5} \\
\hline 20 & - & - & 4,547 & - & - & 4,547 & - & - & 4,547 \\
\hline 30 & - & 15 & 4,532 & - & 1 & 4,546 & - & 1 & 4,546 \\
\hline \multirow[t]{2}{*}{40} & - & 446 & 4,102 & - & 21 & 4,526 & - & 1 & 4,546 \\
\hline & \multicolumn{9}{|c|}{ March 15} \\
\hline 20 & - & - & 4,547 & - & - & 4,547 & - & - & 4,547 \\
\hline 30 & - & 1 & 4,546 & - & 1 & 4,546 & - & 0 & 4,546 \\
\hline \multirow[t]{2}{*}{40} & - & 24 & 4,523 & - & 1 & 4,546 & - & 1 & 4,546 \\
\hline & \multicolumn{9}{|c|}{ March 25} \\
\hline 20 & - & - & 4,547 & - & - & 4,546 & - & - & 4,547 \\
\hline 30 & - & 1 & 4,546 & - & 1 & 4,546 & - & - & 4,547 \\
\hline 40 & 1 & 0 & 4,546 & - & 1 & 4,547 & - & 1 & 4,544 \\
\hline
\end{tabular}


The complete results of this study, with data and spatial configurations in the detailed format of tables and figures, for all studied combinations (cultivar cycle $\mathrm{x}$ soil type $\mathrm{x}$ sowing period $\mathrm{x}$ impact level $\mathrm{x}$ risk level), can be found in Pasinato (2017). Considering the best combination of factors - risk level of $20 \%$, cultivars of group I, type 3 soils with ASWC $75 \mathrm{~mm}$, a low impact level of ASWC $\geq 0.7$, and altitudes above $800 \mathrm{~m}-, 1.3$ million hectares were identified as potentially favorable for growing rainfed wheat in the Cerrado biome, where annual agriculture is currently consolidated; it should be pointed out that, when the
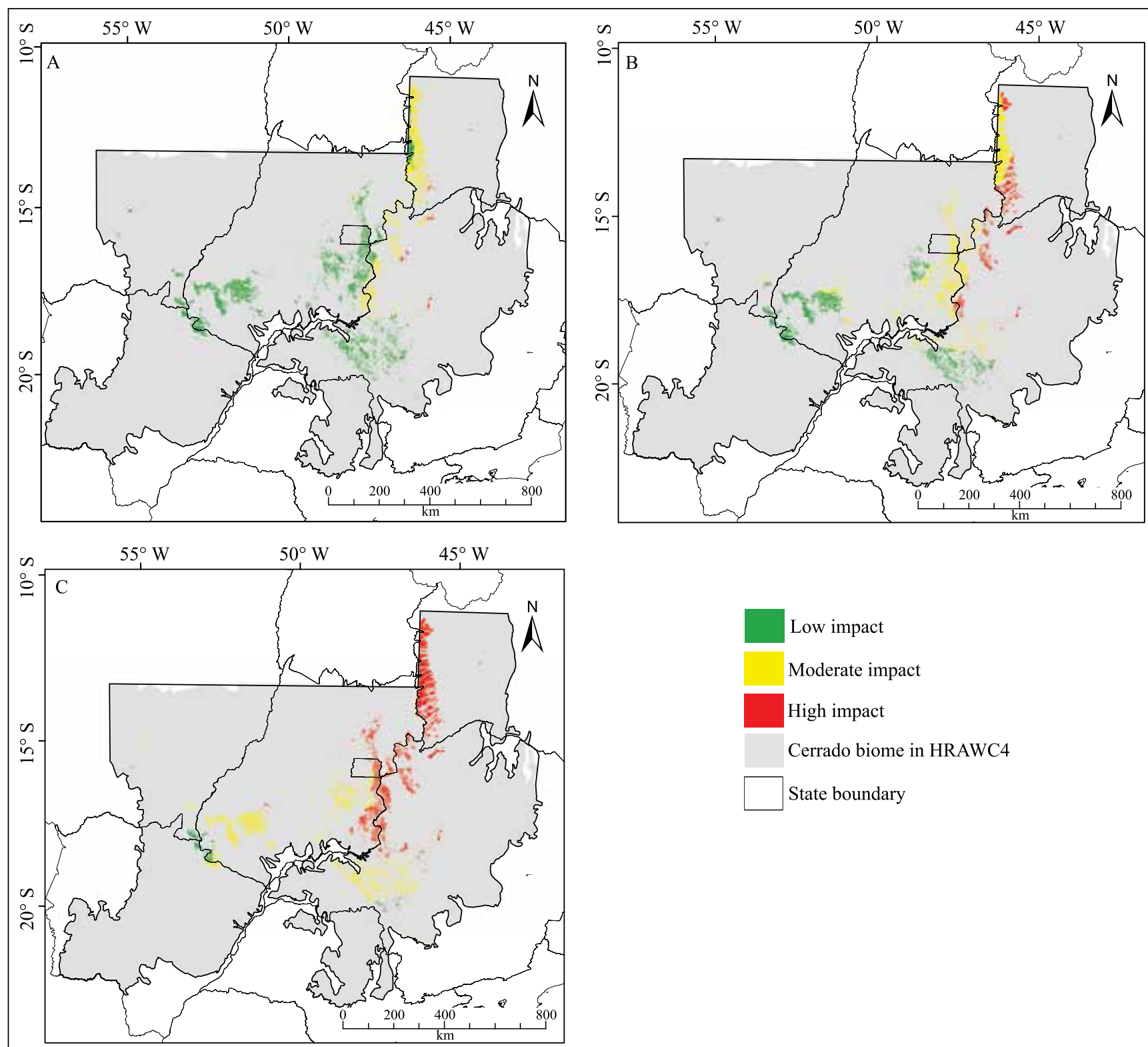

Figure 4. Spatial distribution of the favorable areas for rainfed wheat (Triticum aestivum) cultivars of groups I (A), II (B) and III (C) for low, moderate, and high water restriction impact levels in the homogeneous region of adaptation of wheat cultivars 4 (HRAWC 4) in the Brazilian Cerrado biome, in type 3 soils with an available water storage capacity of 75 mm, and with a risk level of $40 \%$. The results are cross-referenced with the information layers agricultural zoning for climatic risk (ZARC) for rainfed wheat in 2016/2017, area used for annual agriculture, and altitudes above $800 \mathrm{~m}$ for the sowing period centered on February 5. 
risk level was changed to $40 \%$, this area increased to approximately 3.0 million hectares. In summary, these data indicate that the potentially favorable area identified is smaller than the ones reported in previous studies: 2.5 million hectares (Albrecht et al., 2007), approximately 4.0 million hectares (Mingoti et al., 2014), and even 24.9 million hectares (Farias et al., 2016). This discrepancy can be explained by the more general nature of the previous works. In the present study, three restriction criteria were used to determine the potentially favorable area for rainfed wheat: areas with adequate water (ZARC), areas with adequate heat (altitude), and already consolidated areas of cultivation (with annual agriculture).

Regarding water adequacy, the present study took into account the intraregional risk and climatic impacts caused by water deficit, but strictly limited to the Cerrado biome and within the boundaries defined by the HRAWC 4 (Cunha et al., 2011). This is justified by the search for new areas for rainfed wheat cultivation in a region with a well-defined dry season and very different rainfall pattern during the driest and wettest four-month periods.

It is also worth noting that, for rainfed crops, especially grains, the analysis method based on water deficiency in the grain-filling stage can be considered reliable and robust. In this case, water efficiency is defined by the values of the relative evapotranspiration index $(\mathrm{ETr} / \mathrm{ETm})$ expressed by WRSI step 3 in the ZARC studies. This indicator has been used to evaluate environmental effects, particularly those caused by drought, on crop yield, both in Brazil and in other countries (Monteiro et al., 2017).

The crop's restrictions related to heat adequacy were indirectly assessed through altitude ranges. Altitudes above $800 \mathrm{~m}$ were considered most favorable based on several works that address this topic (Cunha et al., 2011). In the Brazilian Cerrado region, the stress caused by high temperatures is one of the main problems affecting the development of wheat and may lead to changes in cycle length until head emergence, plant height, mean grain weight, and grain yield (Cargnin et al., 2006). Studies on wheat crops in several tropical regions of the world have shown that the plant development cycle accelerates at temperatures above $30^{\circ} \mathrm{C}$, which can negatively impact the final crop yield (Ribeiro et al., 2012). A maximum air temperature above $30^{\circ} \mathrm{C}$ predominates in practically the entire study area, especially in February and March. In general, the regions with more adequate temperatures for cultivating this cereal are mainly found in Minas Gerais, Goiás, western Bahia, and Distrito Federal, and coincide with those that have higher altitudes. This result validates the choice of this restriction factor for wheat cultivation in the study region.

In summary, the cultivation of rainfed wheat in the Cerrado biome of the HRAWC 4, an eminently tropical zone, is marked by high temperatures and defined dry and wet seasons. Despite the existence of successful experiments and the demarcation of areas with favorable traits for the cultivation of this cereal according to ZARC rainfed wheat in 2016/2017, technological advances in plant genetics and crop management are still needed for this area to be competitively and sustainably established as a new zone of expansion for wheat production. The environmental conditions of the Brazilian Cerrado may become more inhospitable for the adaptation of wheat given the threat of global warming. According to Asseng et al. (2015), there is evidence that worldwide wheat production may fall by up to $6 \%$ for every $1.0^{\circ} \mathrm{C}$ rise in mean global temperature.

The last restriction factor was only including areas that were used in annual agriculture in 2013 (Mapeamento..., 2015). This allows intensifying land use without the need to expand the wheat crop to areas not yet economically explored with temporary crops.

The wheat-growing areas identified in the present study are potential and valid only if there are no other factors restricting the development of the crop in the indicated sites and seasons. To consolidate a tropical, effectively sustainable, and competitive wheat cultivation in Brazil, it is necessary to implement changes in plant breeding and crop management by developing early-cycle wheat cultivars, improving the tolerance of cultivars both to blast disease for sowing at the beginning of February (Maciel, 2011) and to heat (Cargnin et al., 2009; Pimentel et al., 2015), and better exploring soil water availability. This can be achieved by adopting conservationist principles throughout the Cerrado biome or by taking the genetic route, using regionally adapted cultivars that better explore the deep soil profile due to the effectiveness of their root system or that have mechanisms that increase their water use efficiency (Ribeiro Jr. et al., 2006).

Pesq. agropec. bras., Brasília, v.53, n.7, p.779-790, July 2018 DOI: 10.1590/S0100-204X2018000700001 


\section{Conclusions}

1. Potentially favorable areas for rainfed wheat (Triticum aestivum) cultivation in the Cerrado biome of Brazil are associated with sowing in early February, short-cycle cultivars, and soils with higher water storage capacity.

2. In Brazil, the zones that show the best combination of risk and climatic impacts for rainfed wheat cultivation at altitudes above $800 \mathrm{~m}$ are mainly located in Goiás, Distrito Federal, and Minas Gerais.

3 . The expansion or reduction of the potentially favorable area for rainfed wheat cultivation in the Cerrado biome, where annual agricultural activity is already consolidated, is conditioned by the adoption, in isolation or in combination, of presumed climatic risk levels $(20,30$, or $40 \%)$ and/or impacts (low, moderate, or high).

\section{Acknowledgments}

To Universidade Federal do Rio Grande do Sul (UFRGS), for the opportunity to carry out this work.

\section{References}

ALBRECHT, J.C.; RIBEIRO JÚNIOR, W.Q.; SILVA, M.S. e. Cultivares de trigo para o Cerrado. In: FALEIRO, F.G.; SOUSA, E. dos S. de (Ed.). Pesquisa, desenvolvimento e inovação para o Cerrado. Planaltina: Embrapa Cerrados, 2007. p.61-68.

ASSENG, S.; CAMMARANO, D.; BASSO, B.; CHUNG, U.; ALDERMAN, P.D.; SONDER, K.; REYNOLDS, M.; LOBELL, D.B. Hot spots of wheat yield decline with rising temperatures. Global Change Biology, v.23, p.2464-2472, 2017. DOI: 10.1111/ gcb.13530.

ASSENG, S.; EWERT, F.; MARTRE,P.; RÖTTER, R.P.; LOBELL, D.B.; CAMMARANO, D.; KIMBALL, B.A.; OTTMAN, M.J.; WALL, G.W.; WHITE, J.W.; REYNOLDS, M.P.; ALDERMAN, P.D.; PRASAD, P.V.V.; AGGARWAL, P.K.; ANOTHAI, J.; BASSO, B.; BIERNATH, C.; CHALLINOR, A.J.; DE SANCTIS, G.; DOLTRA, J.; FERERES, E.; GARCIA-VILA, M.; GAYLER, S.; HOOGENBOOM, G.; HUNT, L.A.; IZAURRALDE, R.C.; JABLOUN, M.; JONES, C.D.; KERSEBAUM, K.C.; KOEHLER, A.-K.; MÜLLER, C.; NARESH KUMAR, S.; NENDEL, C.; O'LEARY, G.; OLESEN, J.E.; PALOSUO, T.; PRIESACK, E.; EYSHI REZAEI, E.; RUANE, A.C.; SEMENOV, M.A.; SHCHERBAK, I.; STÖCKLE, C.; STRATONOVITCH, P.; STRECK, T.; SUPIT, I.; TAO, F.; THORBURN, P.J.; WAHA, K.; WANG, E.; WALLACH, D.; WOLF, J.; ZHAO, Z.; ZHU, Y. Rising temperatures reduce global wheat production. Nature Climate Change, v.5, p.143-147, 2015. DOI: 10.1038/nclimate2470.

BARON, C.; CLOPES, A. Sistema de análise regional dos riscos agroclimáticos (SARRA). Paris: CIRAD, 1996.
BOWNE, J.B.; ERWIN, T.A.; JUTTNER, J.; SCHNURBUSCH, T.; LANGRIDGE, P.; BACIC, A.; ROESSNER, U. Drought responses of leaf tissues from wheat cultivars of differing drought tolerance at the metabolite level. Molecular Plant, v.5, p.418-429, 2012. DOI: $10.1093 / \mathrm{mp} / \mathrm{ssr} 114$.

BRASIL. Ministério da Agricultura, Pecuária e Abastecimento. Portaria $^{\circ}$ 256, de 22 de dezembro de 2015. [Aprova o Zoneamento Agrícola de Risco Climático para a cultura de trigo de sequeiro no Distrito Federal, ano-safra 2015/2016, conforme anexo]. Diário Oficial da União, 23 dez. 2015a. Seção 1, p.27.

BRASIL. Ministério da Agricultura, Pecuária e Abastecimento. Portaria $\mathrm{n}^{\mathrm{o}}$ 257, de 22 de dezembro de 2015. [Aprova o Zoneamento Agrícola de Risco Climático para a cultura de trigo de sequeiro no Estado de Goiás, ano-safra 2015/2016, conforme anexo]. Diário Oficial da União, 23 dez. 2015b. Seção 1, p.27-28.

BRASIL. Ministério da Agricultura, Pecuária e Abastecimento. Portaria $\mathrm{n}^{\circ} 258$, de 22 de dezembro de 2015. [Aprova o Zoneamento Agrícola de Risco Climático para a cultura de trigo de sequeiro no Estado de Minas Gerais, ano-safra 2015/2016, conforme anexo]. Diário Oficial da União, $23 \mathrm{dez}$. 2015c. Seção 1, p.28-31.

BRASIL. Ministério da Agricultura, Pecuária e Abastecimento.

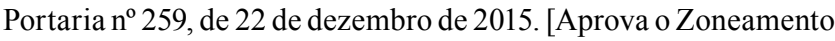
Agrícola de Risco Climático para a cultura de trigo de sequeiro no Estado de Mato Grosso do Sul, ano-safra 2015/2016, conforme anexo]. Diário Oficial da União, 23 dez. 2015d. Seção 1, p.31-32.

BRASIL. Ministério da Agricultura, Pecuária e Abastecimento. Portaria $^{\circ} 260$, de 22 de dezembro de 2015. [Aprova o Zoneamento Agrícola de Risco Climático para a cultura de trigo de sequeiro no Estado de Mato Grosso, ano-safra 2015/2016, conforme anexo]. Diário Oficial da União, 23 dez. 2015e. Seção 1, p.32-33.

BRASIL. Ministério da Agricultura, Pecuária e Abastecimento. Portaria $\mathrm{n}^{\circ} 264$, de 22 de dezembro de 2015. [Aprova o Zoneamento Agrícola de Risco Climático para a cultura de trigo de sequeiro no Estado de São Paulo, ano-safra 2015/2016, conforme anexo]. Diário Oficial da União, 23 dez. 2015f. Seção 1, p.42-45.

BRASIL. Ministério da Agricultura, Pecuária e Abastecimento.

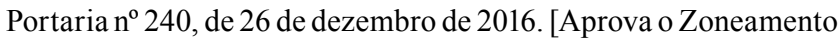
Agrícola de Risco Climático para a cultura de trigo de sequeiro no Distrito Federal, ano-safra 2016/2017, conforme anexo]. Diário Oficial da União, 28 dez. 2016a. Seção 1, p.29.

BRASIL. Ministério da Agricultura, Pecuária e Abastecimento. Portaria $^{\circ}$ 241, de 26 de dezembro de 2016. [Aprova o Zoneamento Agrícola de Risco Climático para a cultura de trigo de sequeiro no Estado de Goiás, ano-safra 2016/2017, conforme anexo]. Diário Oficial da União, 28 dez. 2016b. Seção 1, p.29-33.

BRASIL. Ministério da Agricultura, Pecuária e Abastecimento. Portaria $\mathrm{n}^{\mathrm{O}}$ 242, de 26 de dezembro de 2016. [Aprova o Zoneamento Agrícola de Risco Climático para a cultura de trigo de sequeiro no Estado de Minas Gerais, ano-safra 2016/2017, conforme anexo]. Diário Oficial da União, 28 dez. 2016c. Seção 1, p.33-39.

BRASIL. Ministério da Agricultura, Pecuária e Abastecimento. Portaria $^{\circ}$ 243, de 26 de dezembro de 2016. [Aprova o Zoneamento Agrícola de Risco Climático para a cultura de trigo de sequeiro no Estado de Mato Grosso do Sul, ano-safra 2016/2017, conforme anexo]. Diário Oficial da União, 28 dez. 2016d. Seção 1, p.40-41. 
BRASIL. Ministério da Agricultura, Pecuária e Abastecimento. Portaria $\mathrm{n}^{\circ}$ 244, de 26 de dezembro de 2016. [Aprova o Zoneamento Agrícola de Risco Climático para a cultura de trigo de sequeiro no Estado de Mato Grosso, ano-safra 2016/2017, conforme anexo]. Diário Oficial da União, 28 dez. 2016e. Seção 1, p.41-42.

BRASIL. Ministério da Agricultura, Pecuária e Abastecimento. Portaria $n^{\circ} 248$, de 26 de dezembro de 2016. [Aprova o Zoneamento Agrícola de Risco Climático para a cultura de trigo de sequeiro no Estado de São Paulo, ano-safra 2016/2017, conforme anexo]. Diário Oficial da União, 28 dez. 2016f. Seção 1, p.59-63.

BRASIL. Ministério da Agricultura, Pecuária e Abastecimento. Zoneamento Agrícola de Risco Climático. Available at: $<$ http:// indicadores.agricultura.gov.br/zarc/index.htm>. Accessed on: June 252018.

CARGNIN, A.; SOUZA, M.A. de; FRONZA, V.; ALBRECHT, J.C.; SILVA, M.S. e; SOARES SOBRINHO, J.; YAMANAKA, C.H.; FOGAÇA, C.M. Progressos do melhoramento genético do trigo de sequeiro no cerrado de Minas Gerais entre 1976 e 2005. Planaltina: Embrapa Cerrados, 2009. 17p. (Embrapa Cerrados. Boletim de pesquisa e desenvolvimento, 242).

CARGNIN, A.; SOUZA, M.A. de; ROCHA, V.S.; MACHADO, J.C.; PICCINI, E. Tolerância ao estresse térmico em genótipos de trigo. Pesquisa Agropecuária Brasileira, v.41, p.1269-1276, 2006. DOI: 10.1590/S0100-204X2006000800009.

CHENU, K.; COOPER, M.; HAMMER, G.L.; MATHEWS, K.L.; DRECCER, M.F.; CHAPMAN, S.C. Environment characterization as an aid to wheat improvement: interpreting genotype-environment interactions by modelling water-deficit patterns in North-Eastern Australia. Journal of Experimental Botany, v.62, p.1743-1755, 2011. DOI: 10.1093/jxb/erq459.

CONAB. Séries históricas das safras: Trigo-Brasil: série histórica de área plantada, produtividade e produção. Available at: $<$ https:// www.conab.gov.br/info-agro/safras/serie-historica-das-safras/ item/download/20781_c454acb2829efcfcfc9c538cb636f425>. Accessed on: Sept. 222017.

CONDÉ, A.B.T.; COELHO, M.A. de O.; YAMANAKA, C.H.; CORTE, H.R. Adaptabilidade e estabilidade de genótipos de trigo sob cultivo de sequeiro em Minas Gerais. Pesquisa Agropecuária Tropical, v.40, p.45-52, 2010.

CRESPO-HERRERA L.A.; CROSSA, J.; HUERTA-ESPINO, J.; AUTRIQUE, E.; MONDAL, S.; VELU, G.; VARGAS, M.; BRAUN, H.J.; SINGH, R.P. Genetic yield gains in CIMMYT's international elite spring wheat yield trials by modeling the genotype $\times$ environment interaction. Crop Science, v.57, p.789801, 2017. DOI: $10.2135 /$ cropsci2016.06.0553.

CUNHA, G.R. da; PASINATO, A.; PIMENTEL, M.B.M.; HAAS, J.C.; MALUF, J.R.T.; PIRES, J.L.F.; DALMAGO, G.A.; SANTI, A. Regiões para trigo no Brasil: ensaios de $\mathrm{VCU}$, zoneamento agrícola e época de semeadura. In: PIRES, J.L.F.; VARGAS, L.; CUNHA, G.R. da (Ed.). Trigo no Brasil: bases para produção competitiva e sustentável. Passo Fundo: Embrapa Trigo, 2011. p. 27-40.

FARIAS, A.R.; MINGOTI, R.; HOLLER, W.A.; SPADOTTO, C.A.; LOVISI FILHO, E.; DE MORI, C.; CUNHA, G.R. da; DOSSA, A.A.; FERNANDES, J.M.C.; SILVA, M.S. e. Potencial de produção de trigo no Brasil a partir de diferentes cenários de expansão da área de cultivo. Passo Fundo: Embrapa Trigo 2016. 40p. (Embrapa Trigo. Boletim de pesquisa e desenvolvimento online, 85; Embrapa Gestão Territorial. Boletim de pesquisa e desenvolvimento online, 5).

HARGREAVES, G.H.; SAMANI, Z.A. Reference crop evapotranspiration from ambient air temperature. Chicago: American Society of Agricultural Engineering Meeting, 1985. (Paper 85-2517).

KUMAR, R.R.; GOSWAMI, S.; SHAMIM, M.; DUBEY, K.; SINGH, K.; SINGH, S.; KALA, Y.K.; NIRAJ, R.R.K.; SAKHREY, A.; SINGH, G.P.; GROVER, M.; SINGH, B.; RAI, G.K; RAI, A.K.; CHINNUSAMY, V.; PRAVEEN S. Exploring the heatresponsive chaperones and microsatellite markers associated with terminal heat stress tolerance in developing wheat. Functional \& Integrative Genomics, v.17, p.621-640, 2017.

MACIEL, J.L.N. Magnaporthe oryzae, the blast pathogen: current status and options for its control. CAB Reviews: Perspectives in Agriculture, Veterinary Science, Nutrition and Natural Resources, v.6, p.1-8, 2011. Available at: <https://www.cabdirect. org/cabdirect/abstract/20123020131>. Accessed on: Dec. 152016.

MAPEAMENTO do uso e cobertura da terra do Cerrado: Projeto TerraClass Cerrado 2013. Brasília: MMA, 2015. Available at: <http://www.mma.gov.br/biomas/cerrado/projeto-terraclass $>$. Accessed on: Dec. 152016.

Mingoti, R.; HOller, W.A.; SPADOTTO, C.A. Produção potencial de trigo no Brasil. Campinas: Embrapa Gestão Territorial, 2014. 2p. Available at: <http://www.alice.cnptia. embrapa.br/alice/bitstream/doc/978795/1/SGTEInformativo02. pdf $>$. Accessed on: May 202017.

MISHRA, D.; SHEKHAR, S.; AGRAWAL, L.; CHAKRABORTY, S.; CHAKRABORTY, N. Cultivar-specific high temperature stress responses in bread wheat (Triticum aestivum L.) associated with physicochemical traits and defense pathways. Food Chemistry, v.221, p.1077-1087, 2017. DOI: 10.1016/j.foodchem.2016.11.053.

MONTEIRO, J.E.B.A.; VICTORIA, D. de C.; ALMEIDA, S.L.H. de; OLIVEIRA, A.F. de; ESQUERDO, J.C.D.M.; MACIEL, R.J.S.; NAKAI, A.M.; SIBALDELLI, R.N.R.; EVANGELISTA, B.A.; CUADRA, S.V.; EVANGELISTA, S. Delimitação de regiões agroclimaticamente homogêneas no Brasil. Agrometeoros, v.25, p.27-35, 2017.

OLIVEIRA, D.M. de; SOUZA, M.A. de; ROCHA, V.S.; ASSIS, J.C. de. Desempenho de genitores e populações segregantes de trigo sob estresse de calor. Bragantia, v.70, p.25-32, 2011. DOI: 10.1590/S0006-87052011000100005.

PASINATO, A. Potencialidades e limitações para a expansão do cultivo de trigo sequeiro no bioma Cerrado do Brasil Central. 2017. 126p. Dissertação (Mestrado) - Universidade Federal do Rio Grande do Sul, Porto Alegre.

PIMENTEL, A.J.B; ROCHA, J.R. do A.S. de C.; SOUZA, M.A. de; RIBEIRO, G.; SILVA, C.R.; OLIVEIRA, I.C.M. Characterization of heat tolerance in wheat cultivars and effects on production components. Revista Ceres, v.62, p.191-198, 2015. DOI: $10.1590 / 0034-737 X 201562020009$. 
POERSCH-BORTOLON, L.B.; PEREIRA, J.F.; NHANI JUNIOR, A.; SOTO GONZÁLES, H.H.; TORRES, G.A.M.; CONSOLI, L.; ARENHART, R.A.; BODANESE-ZANETTINI, M.H.; MARGIS-PINHEIRO, M. Gene expression analysis reveals important pathways for drought response in leaves and roots of a wheat cultivar adapted to rainfed cropping in the Cerrado biome. Genetics and Molecular Biology, v.39, p.629-645, 2016. DOI: 10.1590/1678-4685-gmb-2015-0327.

RIBEIRO JR., W.Q.; RAMOS, M.L.G.; VASCONCELOS, U.; TRINDADE, M. da G.; FERREIRA, F.M.; SIQUEIRA, M.M.H.; SILVA, H.L.M. da; RODRIGUES, G.C.; GUERRA, A.F.; ROCHA, O.C.; AMÁBILE, R.F.; ALBUQUERQUE, A.C.; SÓ e SILVA, M.; ALBRECHT, J.C.; DURÃES, F.O.M. Fenotipagem para tolerância à seca visando o melhoramento genético do trigo no cerrado. Passo Fundo: Embrapa Trigo, 2006. 17p. (Embrapa Trigo. Circular técnica online, 21). Available at: $<$ https://ainfo.
cnptia.embrapa.br/digital/bitstream/CNPT-2010/40360/1/p-ci21. pdf $>$. Accessed on: Mar. 152017.

RIBEIRO, G.; PIMENTE, A.J.B.; SOUZA, M.A. de, ROCHA, J.R. do A.S. de C.; FONSECA, W.B. da. Estresse por altas temperaturas em trigo: impacto no desenvolvimento e mecanismos de tolerância. Revista Brasileira de Agrociência, v.18 n.2-4, p.133-142, 2012. DOI: 10.18539/CAST.V18I2.2502.

TILMAN, D.; BALZER, C.; HILL, J.; BEFORT, B.L. Global food demand and the sustainable intensification of agriculture. Proceedings of the National Academy of Sciences of the United States of America, v.108, p.20260-20264, 2011. DOI: 10.1073/ pnas. 1116437108.

UNITED STATES GEOLOGICAL SURVEY. EarthExplorer. Available at: $<$ https://earthexplorer.usgs.gov/>. Accessed on: June 252018

$\overline{\text { Received on July 21, } 2017 \text { and accepted on October 9, } 2017}$ 